\title{
Medication errors: scope and prevention strategies
}

\author{
Luigi Brunetti ${ }^{1}$, Dong-Churl Suh ${ }^{2}$
}

1. Rutgers, The State University of New Jersey, USA. 2. College of Phamacy, Chung-Ang University, Republic of Korea

Correspondence: Dong-Churl Suh. Address: College of Pharmacy, Chung-Ang University, 221 Heukseok-dong, Dongjak-gu, Seoul, Republic of Korea. E-mail: dongsuh75@gmail.com

Received: July 18, 2012

DOI : $10.5430 /$ jha.v1n2p54
Accepted: August 18, 2012

URL: http://dx.doi.org/10.5430/jha.v1n2p54

Published: December 1, 2012

\section{Abstract}

Background: Medication errors are a significant public health concern. Although significant advances have been made, errors are still relatively common and represent an opportunity for healthcare improvement.

Methodology/Principal findings: Since the publication of To Err is Human, medication errors have been under tremendous scrutiny. Organizations have moved towards a non-punitive approach to evaluating errors. This approach to medication errors has aided in identifying common pathways to medication errors and improving understanding regarding the anatomy of a medication error. As a result, prevention strategies have been developed to target common themes contributing to errors. Error prevention strategies may target common contributors of medication errors, broadly grouped as performance lapses, lack of knowledge, and lack or failure of safety systems. Strategies to thwart medication errors range from process improvement to integration of technology in the health care environment.

Conclusions/Significance: Organizations should devote resources to address medication error prevention strategies in an effort to improve patient outcomes and decrease morbidity and mortality associated with medication errors.

\section{Key words}

Medication error, Computerized physician order entry, Bar code medication administration, Adverse drug event

\section{I ntroduction}

It is estimated that an error occurs at some point in the medication use process in 5 to $14 \%$ of medication doses dispensed ${ }^{[1-4]}$. Medication errors and preventable adverse drug events have a variety of public health implications ranging from increased hospital length of stay, detrimental effects on quality of life, and death. Approximately 1 to $10 \%$ of medication errors are associated with patient harm ${ }^{[4-7]}$. Prevention of medication errors continues to be an important public health concern.

In order to reduce the incidence of medication errors and provide patients with safe and effective care, practitioners should be familiar with the literature and strategies to prevent medication errors. The objectives of this review are to highlight common contributors to medication errors and to present possible prevention strategies-enhancing communication, technology, education, and encouraging voluntary reporting. 


\section{Literature retrieval}

Literature retrieval was accessed through MEDLINE/PubMed (1950-June 2012), Web of Science (1980-June 2012), and Google Scholar using the terms medication error, computerized physician order entry, bar coded medication administration, medication reconciliation, and medication management. References from publications identified were reviewed for additional resources. Only articles in English were reviewed and articles that represented controlled clinical evaluations were given priority for inclusion in the review.

\section{Background/ Epidemiology}

There are a multitude of terms used to describe and define medication errors in the literature. As a result, epidemiological studies evaluating medication errors are difficult to compare given the differences in identifying the outcome. The National Coordinating Council for Medication Error Reporting and Prevention (NCC MERP) created an international definition in an effort to standardize medication error definition. NCC MERP has defined a medication error as "any preventable event that may cause or lead to inappropriate medication use or patient harm while the medication is in the control of the healthcare professional, patient, or consumer. Such events may be related to professional practice, healthcare products, procedures, and systems, including prescribing, order communication, product labeling, packaging, and nomenclature, compounding, dispensing, distribution, administration, education, monitoring, and use" ${ }^{\text {[8] }}$. NCC MERP has also proposed a medication error index intended to categorize errors based on severity or outcome of the medication error. The index is divided into four main categories and nine subcategories (Figure $1{ }^{\left[{ }^{[8]}\right.}$. As evident in this definition, the medication use process is complex, hence the susceptibility to error. Although the NCC MERP definition is commonly used to categorize medication errors in studies, it was originally developed for medication error reporting rather than detection. The Institute of Medicine (IOM) has provided a broader definition for medication errors to include errors of omission. IOM defines a medication error "as the failure of a planned action to be completed as intended (i.e., error of execution), or the use of a wrong plan to achieve an aim (i.e., error of planning). An error may be an act of commission or an act of omission" [9]. NCC MERP also incorporates "near misses" into their schema (i.e., NCC MERP category A). A "near miss" may be defined as circumstances or occurrences that presented a risk but did not cause patient harm ${ }^{[8]}$. The reporting of these "near misses" or potential medication errors are critical and a necessity in order to improve patient safety. Learning from these potential errors is an opportunity to identify circumstances that are prone to errors and develop mechanisms to thwart the occurrence of a medication error. Overall, there is ambiguity in the definition in medication errors that contributes to variation in study results. Future studies are needed to develop a standard definition for medication errors ${ }^{[10]}$.

\section{NCC MERP Index for Categorizing Medication Errors}

Figure 1. NCC MERP index for categorizing medication errors.

(C) 2001 National Coordinating Council for Medication Error Reporting and Prevention. All Rights Reserved.
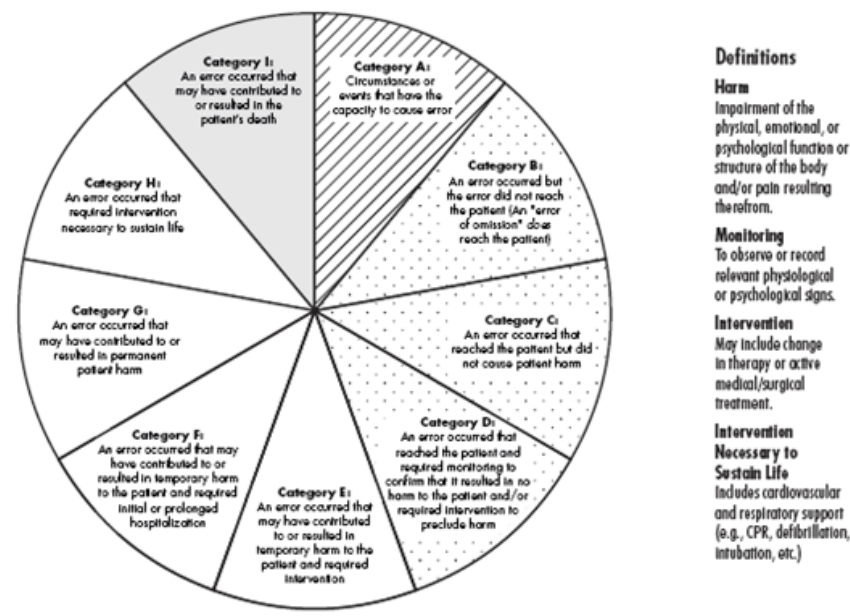
Some populations may be particularly vulnerable to harm resultant to medication errors. The elderly have the highest rate of death from medication errors ${ }^{[11]}$. Several factors present in the elderly population contribute to this increased risk including, polypharmacy, increased drug sensitivity, drug-disease interactions, and unnecessary drug utilization ${ }^{[12]}$. Likewise, the pediatric population is also at an increased risk for medication errors. It has been reported that a medication error impacts 1 in 10 pediatric hospital admissions and injures thousands of children annually ${ }^{[3,13]}$.

Each year medication errors are thought to account for 7000 deaths ${ }^{[9]}$. There are a wide variety of error rates reported in the literature. In one study of 36 facilities, the medication error rate was reported as $14.6 \%{ }^{[14]}$. Another study of 1116 hospitals reported that approximately $5 \%$ of all admitted patients experienced a medication error during their hospital stay ${ }^{[15]}$. Reported medication error rates in the prescribing stage of the medication use process in the hospital setting ranged from 0.61 to 53 per 1000 orders ${ }^{[9]}$. Medication error rates are higher in the pediatric population with $4.2 \%$ to $24 \%$ of pediatric prescriptions containing an error ${ }^{[3,16]}$. The disparity in reported error rates is likely related to the voluntary nature of reporting as well as definitions used in identifying medication errors. It is likely that actual medication error rates are higher than those reported.

In terms of financial impact on the healthcare system, drug related morbidity and mortality costs the United States between $\$ 76.6$ to $\$ 136$ billion annually ${ }^{[17]}$. Further, the negative consequences of medication errors in terms of reputation, psyche, and loss of life are immeasurable. It has been estimated that 2 out of every 100 hospital admissions will experience a preventable adverse drug event and the occurrence of a preventable adverse drug event increases hospitalization costs by $\$ 4,700$ per event. Application of these figures to a 700-bed hospital yields an increased cost of approximately \$2.8 million annually ${ }^{[18]}$. In the ambulatory setting, adverse drug events cost the healthcare system an approximate $\$ 8$ billion annually ${ }^{[19]}$. Overall, the cost of medication errors has not been clearly defined and data in the pediatric and psychiatric population are scare ${ }^{[9]}$. Most of the available data are from the hospital setting and related to additional costs incurred.

\section{Mitigating factors in medication errors}

There have been a variety of models used to categorize the causes of medication errors. One such categorization scheme suggests categorizing the causes of errors into three silos; 1) performance lapses; 2) lack of knowledge; and 3) lack or failure of safety systems ${ }^{[9]}$. Many medication errors fall into the category of lack or failure of safety systems. Healthcare professionals do not intentionally commit errors; however, inadequate systems predispose individuals to committing errors. In one analysis, $78 \%$ of errors were caused by seven system failures, with the leading problem (28\%) attributed to failure to disseminate drug information ${ }^{[20]}$. Systems failure is further substantiated by the United States Pharmacoepeia's MEDMARX experience. Reviews of these data suggest that there are a multitude of causes for medication errors further substantiating the need for a systems approach ${ }^{[21,22]}$.

In each of the medication use phases (prescribing, ordering/transcribing, dispensing, and administration), there is a potential for a medication error to occur. Elements such as missing patient information, patient education, inadequate drug information, impaired communication, staffing inadequacies, product labeling and nomenclature, staff education, and competency may interrupt the medication use process and contribute to a medication error (IOM). Often, medication errors are a result of multiple failures rather than a single deviation.

A common theme in medication errors is lack of communication ${ }^{[23]}$. Communication was the leading cause of sentinel events in 2010 and among the top 3 causes over the past several years according to the Joint Commission. Approximately $60 \%$ of sentinel events list communication as a root cause. In terms of medication errors, communication was listed as one of the root causes in approximately 70\% of sentinel events reported between 2004 through third quarter $2010^{\text {[24] }}$. 
Although all medications have error potential, agents with narrow therapeutic indices are more likely to cause patient harm. The Institute for Safe Medication Practices (ISMP) has published a list of high-alert medications. The use of medications on this list requires additional safeguards to ensure patient safety. Many high-alert medications highlighted by ISMP are administered by the intravenous route (i.e., heparin, insulin, electrolytes). The use of parenteral medications is associated with the highest risk of harm; therefore, the prevention of errors with medications administered by the parenteral route should be of high priority ${ }^{[25]}$.

\section{General recommendations to prevent medication errors (Table 1)}

\subsection{Communication}

The healthcare environment is fast-paced and pressure ridden. It is well established that poor communication can have devastating consequences in the healthcare environment. It has been estimated that $75 \%$ of transcription errors are a result of distractions ${ }^{[26]}$. One analysis quantifying the impact of interruptions on patient safety found that interruptions were associated with a $12.1 \%$ increase in procedural failures and a $12.7 \%$ increase in clinical errors ${ }^{[27]}$. In the same analysis, the authors found that nurse experience was not protective against making clinical errors in the presence of interruptions. These data highlight the importance of designing effective work environments in order to minimize error risk potential. Abbreviations also have a negative impact on communication and have been linked to medication errors. In one analysis of a total of 643,151 medication errors reported to the MEDMARX program 29,974 (4.7\%) were attributed to abbreviation use ${ }^{[28]}$. In order to minimize error potential, distractions should be kept to a minimum, especially in areas where medication orders are processed. Furthermore, abbreviation use should be discouraged especially those appearing on the Joint Commission "Do-not use list". Open dialogue should be encouraged between disciplines in order to minimize miscommunication.

Table 1. Medication errors: contributing factors and strategies to mitigate

\begin{tabular}{|c|c|}
\hline Contributing factor to error & Strategy to mitigate \\
\hline Performance lapse & $\begin{array}{l}\text { - Use a peer review process to dissect medication errors and address } \\
\text { performance issues. } \\
\text { - } \quad \text { Review health records to identify and address performance lapses. }\end{array}$ \\
\hline Lack of knowledge & $\begin{array}{l}\text { - Clinician and patient education are critical. Ensure methods are } \\
\text { tailored for the specific population. } \\
\text { - } \quad \text { Use various methods to relay information throughout the facility. } \\
\text { - Incorporate pharmacists into patient care teams. }\end{array}$ \\
\hline Lack or failure of safety systems & $\begin{array}{ll}\text { - } & \text { Computerized physician order entry (with decision support) } \\
\text { - } & \text { Bar-code medication administration } \\
\text { - } & \text { Identification of high risk medications and populations } \\
\text { - } & \text { Formulary management } \\
\text { - } & \text { Review health records to identify system failures. } \\
\text { - } & \text { Reporting is critical in order to identify areas for improvement. }\end{array}$ \\
\hline
\end{tabular}

It is also essential for practitioners to communicate with patients. A recent analysis demonstrated that one-third of 651 hospital inpatients had a medication error present on admission ${ }^{[29]}$. Eighty-five percent of these errors originated from poor medication histories. These data suggest that by communicating with patients and reconciling medication histories, a significant number of medication errors can be averted. The Joint Commission designated medication reconciliation as a national patient safety goal in $2005{ }^{[30]}$. Organizations should develop a process to accurately reconcile patient Published by Sciedu Press 
medications. An electronic medication reconciliation tool and process improvement has demonstrated a reduction in potential adverse drug events related to medication discrepancies by $28 \%$ (RR 0.72; 95\% CI, $0.52-0.99)^{[31]}$.

\subsection{Computerized physician order entry}

Computerized physician order entry (CPOE) with decision support has the potential to reduce medication errors. The majority of studies have demonstrated a reduction of medication errors in the adult population by 13\% to $86 \%$ (IOM 2006). In the pediatric population the reduction in medication errors has not been as great, ranging from $7 \%$ to $41 \%{ }^{[32-37]}$. While the evidence supporting CPOE is overwhelming, there are data in the pediatric population demonstrating approximately a threefold increase in mortality after implementation ${ }^{[36]}$. More recent data in the pediatric population, however, have demonstrated a significant decrease in mortality by $20 \%{ }^{[38]}$. Ultimately, institutions implementing CPOE should monitor the performance of their systems to ensure optimal outcomes. Despite evidence that CPOE significantly reduces medication errors, poor design, implementation, planning and lack of decision support may introduce new errors ${ }^{[39]}$. Also a concern are the unintended consequences when using some features of CPOE. For example, the uses of "hard-stop" alerts are extremely effective in preventing drug interactions; however, may cause delays in time sensitive medications leading to negative outcomes ${ }^{[40]}$. Using CPOE with decision support and pharmacist monitoring is another strategy to aid in the realization of this technology. One analysis of antibiotic orders found the incidence of inappropriate dosing was decreased by approximately $80 \%$ using the aforementioned strategy ${ }^{[41]}$. While decision support is beneficial, judicious use of alerts is a necessity. Override rates of decision support functions may be increased as a result of clinician alert fatigue ${ }^{[42]}$. Design and appropriate execution of CPOE is essential for it to deliver its promises in error reduction. Institutions should be prepared to customize the features of their CPOE systems in order to accommodate the unique populations that they may serve ${ }^{[43]}$.

Institutions should also be cognizant that although CPOE is an important component of a closed loop medication management system integration with other technologies (i.e., bar coded medication administration (BCMA), electronic medication administration record, and automated medication dispensing devices) and clinical processes are necessary for optimal success ${ }^{[44,45]}$. Closed loop systems help ensure clinicians have access to all of the information collected from the technologies throughout the institution.

\subsection{Bar-code medication administration}

Bar-code medication administration (BCMA) systems are one technology that addresses medication errors occurring at the administration phase of the medication process ${ }^{[46]}$. While CPOE may intercept errors committed during medication prescribing, BCMA may be more effective in intercepting errors committed during medication administration. Errors occurring at the administration node are less likely to be intercepted prior to reaching patients. Leape and colleagues reported that of the medication errors occurring at the administration phase in their study cohort (38\%) only $2 \%$ were intercepted before reaching the patient. These data highlight the need to improve the administration process and the importance of a closed loop medication management system ${ }^{[47,48]}$. BMCA has demonstrated the ability to reduce medication errors by $65 \%$ to $86 \%{ }^{[49,50]}$. Although BMCA has the ability to improve the medication use process, particularly at the administration phase, it may also introduce new types of errors. For example, mislabeling medications that are repackaged to accommodate bar-coding is a common err. These errors occur because not all medications are commercially available in bar-code ready packaging; therefore, pharmacies must repackage medications in order to be compatible with BMCA. It is also critical that the technology is used appropriately and optimized to ensure the greatest benefit. If fired alerts are ignored or overridden, the purpose of the system is defeated. Likewise, if bar code scanning is bypassed or a work-around is used, potential administration errors will not be intercepted. Consequences of workarounds include wrong administration of medications, wrong dosage, wrong times, and incorrect formulations ${ }^{[51]}$. Audits of overrides and bypassed alerts are necessary to optimize the BMCA process. Flawed BCMA design, poor implementation, and lack of consideration to workflow discourage use of BCMA ${ }^{[51]}$. In order to realize the benefits of BCMA, the integration of this technology must be facilitated with the understanding of the institution specific workflow. 


\subsection{Clinician education}

Drug information should be readily accessible to clinicians. In an analysis of medication errors, Leape et al. identified dissemination of drug knowledge as the most common cause of error accounting for $29 \%$ of the 334 errors ${ }^{[47]}$. Availability of information is especially important for infrequently used medications or non-formulary medications since practitioners may be unfamiliar with their use. Sources of information include, but are not limited to, tertiary references, online sources of information, newsletters, and/or inclusion of pharmacists on patient care rounds.

\subsection{Patient education}

It is estimated that 9 out of 10 adults lack the skills needed to manage their health and prevent disease ${ }^{\text {[52] }}$. In a study of 659 public hospital patients, patients with poor health literacy skills were five times more likely to misinterpret their prescriptions than those with adequate skills ${ }^{[53]}$. In another analysis, parents with low health literacy were more 1.7 times likely to give their children the wrong medication dosage ${ }^{[54]}$. It has been established that counseling patients on their medications facilitates the detection of preventable adverse drug events ${ }^{[31]}$. Additionally, patient attitudes and beliefs toward medications impacts medication adherence ${ }^{[55,56]}$. Organizations must bridge the gap in health literacy and improve communication ${ }^{[57]}$. Potential areas for development include the implementation of adherence programs, empowering patients with innovative programs, ensuring education materials are written in the 5th grade reading level, and field-testing educational materials using patient focus groups ${ }^{[58]}$.

\subsection{High-risk medications and vulnerable populations}

Organizations should identify a list of "high-alert" medications because the propensity for harm as a result of a medication error is increased with the use of these agents. ISMP and the Joint Commission have developed a list of "high-alert" medications. Particular attention should be placed on those medications that are administered via the parenteral route. Policies should be created to address the medication use process associated with the use of these medications and provide the necessary drug information to appropriately use the medications. The use of medication in vulnerable populations should also be addressed. Creating standard concentrations and limiting formulary is prudent for all populations, but particularly important in the pediatric population to decrease the likelihood of harm resulting from medication errors. Likewise, identification of potentially inappropriate medication use in the elderly can minimize potential unwanted drug toxicity. The use of the Beers' criteria or the Screening Tool of Older Persons' Prescriptions (STOPP) and Screening Tool to Alert doctors to Right Treatment (START) may help practitioners identify and correct prescribing errors ${ }^{[59-61]}$.

\subsection{Formulary management}

Formulary management should also be considered a tool in the armamentarium against medication errors ${ }^{[62]}$. Medications that are obsolete or confer a greater potential for harm versus benefit compared to similar/alternative medications should be re-evaluated for formulary inclusion. Many preventable adverse drug events are dosage related; therefore, consideration should be placed on formulary dosage restrictions (recommendations).

\subsection{The use of electronic health records}

Health care organizations have large databases available for identifying patients who are not compliant with medications or for the identification of unsafe medication practices ${ }^{[58]}$. In either case, the organization may bring these issues to the attention of the responsible health care provider using traditional (i.e., letters) or electronic approaches (i.e., computer alerts). One important consideration is minimization of unintended "noise" caused by alerts generated by the later method. In a study of 233,537 medication safety alerts generated by an electronic prescribing system over a 9-month period, clinicians accepted only $9.4 \%$ of medication alerts ${ }^{[63]}$. These data highlight the importance of limiting alerts to the most clinically relevant and the most severe so that preventing errors most likely to cause harm is not compromised. Data generated by these methods may also be used to target provider education initiatives (i.e., if there are recurrent themes in the alerts generated) ${ }^{[58]}$. 


\subsection{Reporting system}

Non-punitive reporting is critical in order to identify system failures. Building safer systems requires learning from previous errors ${ }^{[64]}$. In order to foster an environment that learns from its mistakes, it is paramount to move beyond placing blame on an individual ${ }^{[65]}$. This concept should not replace professional accountability; however, it should be noted that the overwhelming majority of medication errors are a result of system failure ${ }^{[47]}$. Organizations should develop processes to encourage non-punitive reporting. It is essential to report medication errors, "near misses", and other problems in order for the medication management system to evolve. Reporting alone is not sufficient and caution should be exercised when acting on the incident without dissecting the anatomy of the error. Systematic evaluation of the incidents and subsequent enhancements in the system processes ensure meaningful corrections. To achieve this level of learning, organizations should ensure psychological safety ${ }^{[66]}$. Psychological safety is defined as "a team climate characterized by interpersonal trust and mutual respect in which people are comfortable being themselves” ${ }^{[67]}$. By fostering this type of environment, individuals are more compelled to inquire, seek feedback, identify system failure, and provide feedback.

The data obtained through these reports should be critically evaluated in order to identify and correct error-prone processes. Nonetheless, voluntary reporting is plagued with under reporting; therefore, organizations should consider other tools to identify areas for improvement. Other approaches include chart review, claims data, incident reporting, administrative database examination, computer monitoring, direct care observation, and/or patient monitoring ${ }^{[64]}$.

\section{Conclusion}

The medication use process is complex. Various strategies may be utilized to safeguard against medication errors such as improving communication, the use of technology, education, and development of policies for high-risk medications. Optimization of this process involves learning from past events-medication errors. Organizations must foster a non-punitive reporting environment in order for the medication use process to evolve into a safer process.

\section{References}

[1] Kohn LT, Corrigan J, Donaldson MS: To err is human: building a safer health system. Washington, D.C.: National Academy Press; 2000.

[2] Krahenbuhl-Melcher A, Schlienger R, Lampert M, Haschke M, Drewe J, Krahenbuhl S: Drug-related problems in hospitals: a review of the recent literature. Drug Saf. 2007; 30(5): 379-407. PMid:17472418

[3] Kaushal R, Bates DW, Landrigan C, McKenna KJ, Clapp MD, Federico F, Goldmann DA: Medication errors and adverse drug events in pediatric inpatients. JAMA. 2001; 285(16): 2114-2120. http://dx.doi.org/10.1001/jama.285.16.2114

[4] Bates DW, Boyle DL, Vander Vliet MB, Schneider J, Leape L: Relationship between medication errors and adverse drug events. J Gen Intern Med. 1995; 10(4): 199-205. PMid:7790981 http://dx.doi.org/10.1007/BF02600255

[5] Zaal RJ, van Doormaal JE, Lenderink AW, Mol PG, Kosterink JG, Egberts TC, Haaijer-Ruskamp FM, van den Bemt PM: Comparison of potential risk factors for medication errors with and without patient harm. Pharmacoepidemiol Drug Saf. 2010; 19(8): 825-833. PMid:20681001 http://dx.doi.org/10.1002/pds.1977

[6] Stavroudis TA, Shore AD, Morlock L, Hicks RW, Bundy D, Miller MR: NICU medication errors: identifying a risk profile for medication errors in the neonatal intensive care unit. J Perinatol. 2010; 30(7): 459-468. PMid:20043010 http://dx.doi.org/10.1038/jp.2009.186

[7] Crespin DJ, Modi AV, Wei D, Williams CE, Greene SB, Pierson S, Hansen RA: Repeat medication errors in nursing homes: Contributing factors and their association with patient harm. Am J Geriatr Pharmacother. 2010; 8(3): 258-270. PMid:20624615 http://dx.doi.org/10.1016/j.amjopharm.2010.05.005

[8] Brixey J, Johnson TR, Zhang J: Evaluating a medical error taxonomy. Proc AMIA Symp. 2002; 71-75. PMid:12463789

[9] Aspden P, Institute of Medicine (U.S.). Committee on Identifying and Preventing Medication Errors.: Preventing medication errors. Washington, DC: National Academies Press; 2007.

[10] Lisby M, Nielsen LP, Brock B, Mainz J: How are medication errors defined? A systematic literature review of definitions and characteristics. Int J Qual Health Care. 2010; 22(6): 507-518. PMid:20956285 http://dx.doi.org/10.1093/intqhc/mzq059 
[11] Phillips J, Beam S, Brinker A, Holquist C, Honig P, Lee LY, Pamer C: Retrospective analysis of mortalities associated with medication errors. Am J Health Syst Pharm. 2001; 58(19): 1835-1841. PMid:11596700

[12] Hanlon JT, Schmader KE, Ruby CM, Weinberger M: Suboptimal prescribing in older inpatients and outpatients. J Am Geriatr Soc. 2001; 49(2): 200-209. PMid:11207875 http://dx.doi.org/10.1046/j.1532-5415.2001.49042.x

[13] Holdsworth MT, Fichtl RE, Behta M, Raisch DW, Mendez-Rico E, Adams A, Greifer M, Bostwick S, Greenwald BM: Incidence and impact of adverse drug events in pediatric inpatients. Arch Pediatr Adolesc Med. 2003; 157(1): 60-65.

http://dx.doi.org/10.1001/archpedi.157.1.60

[14] Flynn EA, Barker KN, Pepper GA, Bates DW, Mikeal RL: Comparison of methods for detecting medication errors in 36 hospitals and skilled-nursing facilities. Am J Health Syst Pharm. 2002; 59(5): 436-446. PMid:11887410

[15] Bond CA, Raehl CL, Franke T: Medication errors in United States hospitals. Pharmacotherapy. 2001; 21(9): $1023-1036$. PMid:11560192 http://dx.doi.org/10.1592/phco.21.13.1023.34617

[16] Fontan JE, Maneglier V, Nguyen VX, Loirat C, Brion F: Medication errors in hospitals: computerized unit dose drug dispensing system versus ward stock distribution system. Pharm World Sci. 2003; 25(3): 112-117. http://dx.doi.org/10.1023/A:1024053514359

[17] Johnson JA, Bootman JL: Drug-related morbidity and mortality. A cost-of-illness model. Arch Intern Med. 1995; 155(18): 1949-1956. PMid:7575048 http://dx.doi.org/10.1001/archinte.1995.00430180043006

[18] Bates DW, Spell N, Cullen DJ, Burdick E, Laird N, Petersen LA, Small SD, Sweitzer BJ, Leape LL: The costs of adverse drug events in hospitalized patients. Adverse Drug Events Prevention Study Group. JAMA. 1997; 277(4): 307-311. http://dx.doi.org/10.1001/jama.277.4.307

[19] Burton MM, Hope C, Murray MD, Hui S, Overhage JM: The cost of adverse drug events in ambulatory care. AMIA Annu Symp Proc. 2007: 90-93. PMid:18693804

[20] Leape LL, Brennan TA, Laird N, Lawthers AG, Localio AR, Barnes BA, Hebert L, Newhouse JP, Weiler PC, Hiatt H: The nature of adverse events in hospitalized patients. Results of the Harvard Medical Practice Study II. N Engl J Med. 1991; 324(6): 377-384. PMid:1824793 http://dx.doi.org/10.1056/NEJM199102073240605

[21] Santell JP: Medication errors: experience of the United States Pharmacopeia (USP). Jt Comm J Qual Patient Saf. 2005; 31(2): 114-119, 161. PMid:15791771

[22] Santell JP, Hicks RW, McMeekin J, Cousins DD: Medication errors: experience of the United States Pharmacopeia (USP) MEDMARX reporting system. J Clin Pharmacol. 2003; 43(7): 760-767. PMid:12856391

[23] Hickner J, Zafar A, Kuo GM, Fagnan LJ, Forjuoh SN, Knox LM, Lynch JT, Stevens BK, Pace WD, Hamlin BN et al: Field test results of a new ambulatory care Medication Error and Adverse Drug Event Reporting System--MEADERS. Ann Fam Med. 2010; 8(6): 517-525. PMid:21060122 http://dx.doi.org/10.1370/afm.1169

[24] Murphy JG, Dunn WF: Medical errors and poor communication. Chest. 2010; 138(6): 1292-1293. PMid:21138880 http://dx.doi.org/10.1378/chest.10-2263

[25] Williams CK, Maddox RR: Implementation of an i.v. medication safety system. Am J Health Syst Pharm. 2005; 62(5):530-536. PMid:15745919

[26] Teichman PG, Caffee AE: Prescription writing to maximize patient safety. Fam Pract Manag. 2002; 9(7): 27-30.

[27] Westbrook JI, Woods A, Rob MI, Dunsmuir WT, Day RO: Association of interruptions with an increased risk and severity of medication administration errors. Arch Intern Med. 2010; 170(8): 683-690. PMid:20421552 http://dx.doi.org/10.1001/archinternmed.2010.65

[28] Brunetti L, Santell JP, Hicks RW: The impact of abbreviations on patient safety. Jt Comm J Qual Patient Saf. 2007; 33(9): 576-583. PMid:17915532

[29] Gleason KM, McDaniel MR, Feinglass J, Baker DW, Lindquist L, Liss D, Noskin GA: Results of the Medications at Transitions and Clinical Handoffs (MATCH) study: an analysis of medication reconciliation errors and risk factors at hospital admission. J Gen Intern Med. 2010; 25(5): 441-447. PMid:20180158 http://dx.doi.org/10.1007/s11606-010-1256-6

[30] Meeting the the joint commission's 2012 national patient safety goals. Oak Brook, IL: Joint Commission Resources. 2012.

[31] Schnipper JL, Hamann C, Ndumele CD, Liang CL, Carty MG, Karson AS, Bhan I, Coley CM, Poon E, Turchin A et al: Effect of an electronic medication reconciliation application and process redesign on potential adverse drug events: a cluster-randomized trial. Arch Intern Med. 2009; 169(8): 771-780. PMid:19398689 http://dx.doi.org/10.1001/archinternmed.2009.51

[32] King WJ, Paice N, Rangrej J, Forestell GJ, Swartz R: The effect of computerized physician order entry on medication errors and adverse drug events in pediatric inpatients. Pediatrics. 2003; 112(3 Pt 1): 506-509. PMid:12949274 http://dx.doi.org/10.1542/peds.112.3.506

[33] Potts AL, Barr FE, Gregory DF, Wright L, Patel NR: Computerized physician order entry and medication errors in a pediatric critical care unit. Pediatrics. 2004; 113(1 Pt 1): 59-63. http://dx.doi.org/10.1542/peds.113.1.59 
[34] Upperman JS, Staley P, Friend K, Neches W, Kazimer D, Benes J, Wiener ES: The impact of hospitalwide computerized physician order entry on medical errors in a pediatric hospital. J Pediatr Surg. 2005; 40(1): 57-59. PMid:15868559 http://dx.doi.org/10.1016/j.jpedsurg.2004.09.024

[35] McPhillips HA, Stille CJ, Smith D, Hecht J, Pearson J, Stull J, Debellis K, Andrade S, Miller M, Kaushal R et al: Potential medication dosing errors in outpatient pediatrics. J Pediatr. 2005; 147(6): 761-767. PMid:16356427 http://dx.doi.org/10.1016/j.jpeds.2005.07.043

[36] Han YY, Carcillo JA, Venkataraman ST, Clark RS, Watson RS, Nguyen TC, Bayir H, Orr RA: Unexpected increased mortality after implementation of a commercially sold computerized physician order entry system. Pediatrics. 2005; 116(6): 1506-1512. PMid:16322178 http://dx.doi.org/10.1542/peds.2005-1287

[37] Walsh KE, Landrigan CP, Adams WG, Vinci RJ, Chessare JB, Cooper MR, Hebert PM, Schainker EG, McLaughlin TJ, Bauchner $\mathrm{H}$ : Effect of computer order entry on prevention of serious medication errors in hospitalized children. Pediatrics. 2008; 121(3): e421-427. PMid:18310162 http://dx.doi.org/10.1542/peds.2007-0220

[38] Longhurst CA, Parast L, Sandborg CI, Widen E, Sullivan J, Hahn JS, Dawes CG, Sharek PJ: Decrease in hospital-wide mortality rate after implementation of a commercially sold computerized physician order entry system. Pediatrics. 2010; 126(1): 14-21. PMid:20439590 http://dx.doi.org/10.1542/peds.2009-3271

[39] Shulman R, Singer M, Goldstone J, Bellingan G: Medication errors: a prospective cohort study of hand-written and computerised physician order entry in the intensive care unit. Crit Care. 2005; 9(5): R516-521.

PMid:16277713 http://dx.doi.org/10.1186/cc3793

[40] Strom BL, Schinnar R, Aberra F, Bilker W, Hennessy S, Leonard CE, Pifer E: Unintended effects of a computerized physician order entry nearly hard-stop alert to prevent a drug interaction: a randomized controlled trial. Arch Intern Med. 2010; 170(17): 1578-1583. PMid:20876410 http://dx.doi.org/10.1001/archinternmed.2010.324

[41] Wang HY, Lu CL, Wu MP, Huang MH, Huang YB: Effectiveness of an integrated CPOE decision-supporting system with clinical pharmacist monitoring practice in preventing antibiotic dosing errors. Int J Clin Pharmacol Ther. 2012; 50(6): 375-382. PMid:22541749

[42] Stultz JS, Nahata MC: Computerized clinical decision support for medication prescribing and utilization in pediatrics. J Am Med Inform Assoc. 2012. PMid:22813761 http://dx.doi.org/10.1136/amiajnl-2011-000798

[43] Tiwari R, Tsapepas DS, Powell JT, Martin ST: Enhancements in healthcare information technology systems: customizing vendor-supplied clinical decision support for a high-risk patient population. J Am Med Inform Assoc. 2012. PMid:22813760 http://dx.doi.org/10.1136/amiajnl-2012-001080

[44] Panosh N, Rew R, Sharpe M: Effect of closed-loop order processing on the time to initial antimicrobial therapy. Am J Health Syst Pharm. 2012; 69(16): 1423-1426. PMid:22855110 http://dx.doi.org/10.2146/ajhp100644

[45] Franklin BD, O'Grady K, Donyai P, Jacklin A, Barber N: The impact of a closed-loop electronic prescribing and administration system on prescribing errors, administration errors and staff time: a before-and-after study. Qual Saf Health Care. 2007; 16(4): 279-284. PMid:17693676 http://dx.doi.org/10.1136/qshc.2006.019497

[46] Poon EG, Keohane CA, Yoon CS, Ditmore M, Bane A, Levtzion-Korach O, Moniz T, Rothschild JM, Kachalia AB, Hayes J et al: Effect of bar-code technology on the safety of medication administration. N Engl J Med. 2010; 362(18): 1698-1707. PMid:20445181 http://dx.doi.org/10.1056/NEJMsa0907115

[47] Leape LL, Bates DW, Cullen DJ, Cooper J, Demonaco HJ, Gallivan T, Hallisey R, Ives J, Laird N, Laffel G et al: Systems analysis of adverse drug events. ADE Prevention Study Group. JAMA. 1995; 274(1): 35-43. http://dx.doi.org/10.1001/jama.274.1.35

[48] Lawrence D: The final hurdle. When it comes to closed-loop medication administration, the final step is the most perilous. Healthc Inform. 2008; 25(8): 18, 20, 22 passim.

[49] Johnson CL, Carlson RA, Tucker CL, Willette C: Using BCMA software to improve patient safety in Veterans Administration Medical Centers. J Healthc Inf Manag. 2002; 16(1): 46-51.

[50] Puckett F: Medication-management component of a point-of-care information system. Am J Health Syst Pharm. 1995; 52(12): 1305-1309. PMid:7656117

[51] Koppel R, Wetterneck T, Telles JL, Karsh BT: Workarounds to barcode medication administration systems: their occurrences, causes, and threats to patient safety. J Am Med Inform Assoc. 2008; 15(4): 408-423. PMid:18436903 http://dx.doi.org/10.1197/jamia.M2616

[52] Kutner MA, National Center for Education Statistics.: Literacy in everyday life: results from the 2003 National Assessment of Adult Literacy. Washington, DC: National Center for Education Statistics; 2007.

[53] Williams MV, Parker RM, Baker DW, Parikh NS, Pitkin K, Coates WC, Nurss JR: Inadequate functional health literacy among patients at two public hospitals. JAMA. 1995; 274(21): 1677-1682. http://dx.doi.org/10.1001/jama.1995.03530210031026 
[54] Yin HS, Mendelsohn AL, Wolf MS, Parker RM, Fierman A, van Schaick L, Bazan IS, Kline MD, Dreyer BP: Parents' medication administration errors: role of dosing instruments and health literacy. Arch Pediatr Adolesc Med. 2010; 164(2): 181-186. http://dx.doi.org/10.1001/archpediatrics.2009.269

[55] Gatti ME, Jacobson KL, Gazmararian JA, Schmotzer B, Kripalani S: Relationships between beliefs about medications and adherence. Am J Health Syst Pharm. 2009; 66(7): 657-664. PMid:19299373 http://dx.doi.org/10.2146/ajhp080064

[56] Phatak HM, Thomas J, 3rd: Relationships between beliefs about medications and nonadherence to prescribed chronic medications. Ann Pharmacother. 2006; 40(10): 1737-1742. PMid:16985088 http://dx.doi.org/10.1345/aph.1H153

[57] DeWalt DA: Ensuring safe and effective use of medication and health care: perfecting the dismount. JAMA. 2010; 304(23): 2641-2642. PMid:21119075 http://dx.doi.org/10.1001/jama.2010.1844

[58] Grissinger MC, Globus NJ, Fricker MP, Jr.: The role of managed care pharmacy in reducing medication errors. J Manag Care Pharm. 2003; 9(1): 62-65. PMid:14613363

[59] Fick DM, Cooper JW, Wade WE, Waller JL, Maclean JR, Beers MH: Updating the Beers criteria for potentially inappropriate medication use in older adults: results of a US consensus panel of experts. Arch Intern Med. 2003; 163(22): 2716-2724. PMid:14662625 http://dx.doi.org/10.1001/archinte.163.22.2716

[60] Gallagher P, O'Mahony D: STOPP (Screening Tool of Older Persons' potentially inappropriate Prescriptions): application to acutely ill elderly patients and comparison with Beers' criteria. Age Ageing. 2008; 37(6): 673-679. PMid:18829684 http://dx.doi.org/10.1093/ageing/afn197

[61] American Geriatrics Society updated Beers Criteria for potentially inappropriate medication use in older adults. J Am Geriatr Soc. 2012; 60(4): 616-631. PMid:22376048 http://dx.doi.org/10.1111/j.1532-5415.2012.03923.x

[62] Lehmann DF, Guharoy R, Page N, Hirschman K, Ploutz-Snyder R, Medicis J: Formulary management as a tool to improve medication use and gain physician support. Am J Health Syst Pharm. 2007; 64(5): 464-466. PMid:17322158 http://dx.doi.org/10.2146/ajhp060332

[63] Isaac T, Weissman JS, Davis RB, Massagli M, Cyrulik A, Sands DZ, Weingart SN: Overrides of medication alerts in ambulatory care. Arch Intern Med. 2009; 169(3): 305-311. PMid:19204222 http://dx.doi.org/10.1001/archinternmed.2008.551

[64] Montesi G, Lechi A: Prevention of medication errors: detection and audit. Br J Clin Pharmacol. 2009; 67(6): 651-655. PMid:19594533 http://dx.doi.org/10.1111/j.1365-2125.2009.03422.x

[65] Edmondson AC: Learning from failure in health care: frequent opportunities, pervasive barriers. Qual Saf Health Care. $2004 ; 13$ Suppl 2: ii3-9. PMid:15576689 http://dx.doi.org/10.1136/qshc.2003.009597

[66] Edmondson AC: The competitive imperative of learning. Harv Bus Rev. 2008; 86(7-8): 60-67, 160.

[67] Edmondson A: Psychological safety and learning behavior in work teams. Administrative Science Quarterly. $1999 ; 44: 350-383$. http://dx.doi.org/10.2307/2666999 